\title{
ELECTROLYTE BALANCES DURING ARTIFICIAL FEVER WITH SPECIAL REFERENCE TO LOSS THROUGH THE SKIN ${ }^{1}$
}

\author{
By E. HENRY KEUTMANN, SAMUEL H. BASSETT, AND STAFFORD L. WARREN \\ (From the Department of Medicine, University of Rochester School of Medicine and Dentistry, \\ and the Medical Clinics of the Strong Memorial and Rochester \\ Municipal Hospitals, Rochester, N. Y.)
}

(Received for publication December 2, 1938)

The purpose of this investigation was to study the electrolyte and fluid loss through sweating during sustained artificial fever therapy. Complete data are difficult to obtain, yet a sufficient number of results were observed from the four patients examined to prove of value to those interested in the general problem of water and electrolyte balance. The situation of the patient who is placed in a heated cabinet in order that an artificial fever may be produced, is analogous in many respects to that of the individual whose body is exposed to the heat of the desert or to the hot atmospheres of certain industries, except that during the artificially induced fever the patient does not breathe heated air. When the temperature of the external environment exceeds that of the body, dissipation of heat is accomplished by evaporation of water from the skin and lungs $(1,2)$. The body resists the attempt to raise its temperature above normal, and physiological mechanisms for thermal regulation are brought into action. The superficial vessels dilate; the flow of blood to the skin is increased; the sweat glands become intensely active, and the respirations become deeper and more frequent. Perhaps the most serious consequences of these regulatory efforts are the rapid losses of salt and water through sweating. If such losses are not replaced promptly, the fluid and electrolyte reserves of the body are placed under severe strain. The rapid depletion of sodium chloride is of particular interest since it can lead to a state of exhaustion with muscle cramps, abdominal pain and ultimately to circulatory collapse $(3,4)$. According to Moon (5) and Loeb et al. (6) shock is a common accompaniment of marked reduction of body electrolytes. Shocklike states (7) and symptoms simulating heat cramps have been noted by the present authors,

1 This study was partially supported by a grant from the Rockefeller Foundation. although they are not commonly observed in routine practice.

Evidence of severe dehydration during the course of artificial fever has been presented by Gibson and Kopp (8). They report reductions of plasma volume in excess of 20 per cent, and net losses of weight that were frequently greater than $2.5 \mathrm{kgm}$. It is likely that the methods used to produce and maintain the artificial fever may have some influence upon the extent of the losses reported (8). While it is probable that some degree of dehydration has occurred in many instances with present methods, it is unlikely that dislocations of water and electrolyte balance represent the sole cause of all the untoward sequelae and the occasional fatal accidents reported in the literature $(7,9,10,11,12)$. On the other hand, disturbance in hydration and electrolyte concentration is not to be minimized since it has a definite bearing on the tolerance of fever by the individual patient. The implications of the latter statement are illustrated by data on salt and water balances kept during the treatment of four patients with artificial fever.

\section{SUBJECTS}

All of the patients were suffering from rheumatoid arthritis, but were normal in other respects. No fever was present except on the days of induced hyperthermia. Two patients were studied during a short period of fever which resembled the routine procedure for rheumatoid arthritis $\left(40.5^{\circ}\right.$ C. for four hours). Two were subjected to a lower temperature $\left(39.5^{\circ} \mathrm{C}\right.$.) for a more protracted period. In these two it is of interest that the man (S. B.) was uncomfortable throughout the whole 35-hour period, and the symptoms of cramps and apprehension became so marked as to necessitate termination of the treatment. The other patient (a woman, W. D.) did not show unusual symptoms of any sort and was comfortable during the 48 hours of elevated temperature. Her skin losses were proportionally much smaller than those of Patient S. B.

Artificial fever was produced in the radiant energy cabinet described by Bishop, Lehman, and Warren (20). 
The body temperatures of the patients were determined by means of a suitable resistance thermometer placed in the rectum.

\section{METHODS}

Investigations were carried on in the special metabolic unit of the hospital. Sampling and analyses of food and excreta were performed as previously described (13), except for the following changes and additions. Stools were collected individually in tared glass containers, a suitable amount of distilled water was added, and the mixture weighed and agitated with a mechanical mixer until a uniform suspension was obtained. Aliquots were then weighed into pyrex dishes, dried on a steam bath, and ashed in a muffle furnace between 500 and $600^{\circ} \mathrm{C}$.

Potassium was determined by first precipitating it from a solution of the ash as potassium sodium cobaltinitrite. This precipitate was then decomposed with strong hydrochloric acid and the potassium determined gravimetrically as chloroplatinate. Chlorine in urine, serum, and sweat was determined by the method of Van Slyke and Sendroy (14), that in food and stools according to the method of Birner (15). The sodium content of serum was found by ashing 2 or $3 \mathrm{ml}$. of serum in a platinum dish. The ash was dissolved in dilute hydrochloric acid and transferred to a $50 \mathrm{ml}$. volumetric flask. Sodium free magnesia mixture was added to remove phosphates and the solution made to volume. The sodium was determined in an aliquot of the filtrate by the method of Barber and Kolthoff (14). Carbon dioxide content of the serum was determined by the method of Van Slyke and Neill (14). Serum solids were determined by weighing the serum in a covered weighing bottle, drying in an oven at $80^{\circ}$ C., and dehydrating in a vacuum dessicator until weight was constant.

\section{Diets}

Patients F. P. and $L$. $H$. received a liquid formula made of milk, eggs, and sugar; orange juice was given separately. Patients S. B., and W. D. were given a formula made of powdered milk, lactose, sucrose, malted milk, and water. They also received graham crackers, tomato juice, and lemonade.

All liquid nourishments were made up in large quantities. Weighed aliquots were removed and saved for analysis while the remainder was kept in a refrigerator. Constant daily rations were weighed out on a torsion balance sensitive to $0.02 \mathrm{gram}$. The caloric and protein contents of the diets were estimated with due regard to size and age of the patients. In 3 of the patients, slight losses of weight occurred on these diets. In 2 of them, this loss lasted only for the first few days of the control periods.

Sodium chloride was given in the form of a solution measured with a volumetric pipette. After drinking this solution from a small glass, the latter was rinsed several times with distilled water and the patient drank each rinsing.

During the artificial fever, the diets, as well as salt were withheld from S. B. and W. D. Instead, weak lemonade was given as tolerated. That taken by S. B. during the 2 days of fever contained $\mathbf{4 4 3}$ grams of carbohydrate; that taken by W. D. contained 548 grams of carbohydrate. Patient S. B. also received $165 \mathrm{ml}$. of whiskey.

Fluid intake was kept constant during the control periods. During fever it was increased to the amounts given in Table VIII.

\section{Direct measurement of electrolytes lost through the skin}

An attempt was made to measure the normal loss of electrolyte through the skin by having Patient L. H. spend 24 hours lying in a radiant energy fever cabinet which was kept just warm enough for comfort. A decrease in the urinary excretion of salt on the following day seemed to point to an unusually large secretion of sweat during the day spent in the cabinet. This finding, together with the restriction of normal activity and the considerable discomfort experienced by the subject, led us to abandon this procedure.

Another method was adopted in the case of Patients S. B. and W. D. At the beginning of the day of observation, the subjects were washed with soap and water and then with distilled water. Pajamas and socks washed free of salt were worn for 24 hours. Activity was restricted to walking about the room. The maximum temperatures of the latter are recorded in Table V. Visible sweating was not present. At the end of 24 hours, the clothing was removed and later thoroughly extracted with distilled water in a continuous extractor until chloride free. The patients were again washed in distilled water. This bath water and the extracts of the clothing were concentrated and analysed. The amount of salt recovered was of the same order of magnitude (Table V) as that reported by others $(16,17)$. Determination of the electrolyte content of the sweat during fever was carried out in essentially the same manner. Each patient was washed with soap and water and thoroughly rinsed with distilled water. The mattress in the fever cabinet was covered with rubber sheeting and the pillow with oil silk. Both had been thoroughly scrubbed with distilled water. All cloths and towels used to wipe sweat off the face and head of the individuals had been previously extracted with distilled water, until the washings were chloride free. Sweat which gathered on the rubber sheet was siphoned into a bottle. After the fever treatment, the patient as well as the rubber sheet and pillow were washed with distilled water. The electrolytes were determined on the sweat which had been collected and the combined washings which had been evaporated to a small volume.

\section{Indirect estimates of electrolytes lost through the skin}

Indirect estimates of large losses of salt through the skin have been made by comparing the excretion of salt in the urine during control days with the urinary salt on days when sweating was excessive. The difference is presumably salt eliminated by the skin. Data published by Dill, Jones, Edwards, and Oberg (18) show that under these conditions the secretion by the sweat glands 
can perhaps be measured with fair accuracy. An approximately correct average skin loss is, however, a difficult value to establish when sweating is at a minimum.

The apparent retentions of sodium, chloride, and potassium as computed from analysis of diet, urine, and feces are ordinarily very small. Slight errors in the methods of analysis may be sufficient to cause the secretion of sweat to appear to be considerably greater or smaller than is actually the case. Moreover, changes in the volume of body water or in its concentration of electrolytes may be enough to obscure loss through the skin. In spite of these handicaps indirect estimates of loss of salt in sweat were attempted in Patients S. B. and W. D. Normal control days were selected.

In the first instance these included only a group of days on which changes in weight cancelled each other. The concentrations of sodium and chloride in the serum were at a nearly constant level, and it was assumed that changes in electrolyte concentration in other body fluids would be at a minimum also. Positive sodium and chloride balances were taken as secretion from the skin.

Skin loss

\begin{tabular}{c|c|c|c|c|c}
\hline \hline \multirow{2}{*}{ Patient } & \multicolumn{2}{|c|}{$\begin{array}{c}\text { Indirect estimate on days } \\
\text { when weight changes } \\
\text { cancelled }\end{array}$} & $\begin{array}{c}\text { Found by direct } \\
\text { determination } \\
\text { on a single day }\end{array}$ \\
\cline { 2 - 6 } & Days & $\mathrm{Na}$ & $\mathrm{Cl}$ & $\mathrm{Na}$ & $\mathrm{Cl}$ \\
\hline & & $\begin{array}{c}\text { mgm. } \\
\text { per day }\end{array}$ & $\begin{array}{c}\text { mgm. } \\
\text { per day } \\
\text { S. B........... }\end{array}$ & $\begin{array}{c}\text { mgm. } \\
\text { per day } \\
\text { W. D......... }\end{array}$ & $\begin{array}{c}\text { mgm. } \\
\text { per day } \\
217\end{array}$ \\
\hline
\end{tabular}

The differences between direct determination and indirect estimate were considerable, but as the possibility of analytical errors existed in each method and as measurement of a single day's secretion from the skin could hardly be expected to give an average value, the result was not surprising.

In the second instance all of the control days, both before and after fever, were included. Changes in weight and in nitrogen balance were taken into account, and corrections were made for the differences in volume of cell water and extracellular fluid using the nitrogen balance method of Gamble et al. (19). The apparent loss through the skin was smaller than by the first computation.

\section{Skin loss}

\begin{tabular}{|c|c|c|c|}
\hline \multirow{2}{*}{ Patient } & \multicolumn{3}{|c|}{$\begin{array}{l}\text { Indirect estimate with corrections for } \\
\text { nitrogen balance and change of weight }\end{array}$} \\
\hline & Days & $\mathrm{Na}$ & $\mathrm{Cl}$ \\
\hline 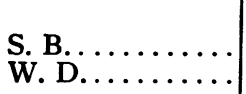 & $\begin{array}{l}13 \\
13\end{array}$ & $\begin{array}{c}\text { mgm. per day } \\
390 \\
79\end{array}$ & $\begin{array}{c}\text { mgm. per day } \\
563 \\
254\end{array}$ \\
\hline
\end{tabular}

Other combinations of control days and other methods were employed to make similar indirect estimates but the 2 examples which have been cited illustrate the discrepancies which were encountered.

The most conservative values for skin losses were those found by the direct method. They have been employed without further attempt at justifying their use in computing balances in Patients S. B. and W. D. Balances for F. P. and L. H. do not include skin losses on control days. The omission, however, does not seem to have had any important bearing on the validity of the data obtained during fever or in the period of recovery.

\section{Clinical observations during fever}

Patient F. P., female, age 44. Induction of fever was begun at $8: 50$ a.m., June 19, 1935. After 80 minutes the temperature had reached $40.5^{\circ} \mathrm{C}$., where it was kept for 4 hours. The pulse rate was between 135 and 155 per minute during the treatment. The systolic blood pressure was $105 \mathrm{~mm} . \mathrm{Hg}$ and the diastolic $80 \mathrm{~mm} . \mathrm{Hg}$ at the beginning. It was not followed during the fever but the pulse remained of good quality. Her color was good and she perspired profusely during the entire treatment. Toward the end of the treatment she complained of headache, backache, and abdominal pain.

Patient $L$. $H$., male, age 43. Induction of fever was begun at 9:50 a.m., April 18, 1935. The temperature reached $40.5^{\circ} \mathrm{C}$. in 3 hours and was kept at that level for 4 hours without untoward effects. The pulse rate was between 125 and 135 per minute during the fever. The systolic blood pressure varied between 80 and $100 \mathrm{~mm}$. $\mathrm{Hg}$, the diastolic between 50 and $60 \mathrm{~mm} . \mathrm{Hg}$. Sweating was profuse during the period of induction, less obvious thereafter.

Patient S. B., male, age 41. Induction of fever was begun at 9:00 a.m., August 12, 1936. In 70 minutes the temperature had reached $39.5^{\circ} \mathrm{C}$., where it was kept for 34 hours. During the first 4 hours, his pulse rate was about 140 per minute. Thereafter it decreased gradually and remained between 100 and 120 per minute. The systolic blood pressure was $120 \mathrm{~mm}$. $\mathrm{Hg}$ and the diastolic $70 \mathrm{~mm}$. at the beginning of treatment. During the fever the systolic pressure varied between 88 and $115 \mathrm{~mm} . \mathrm{Hg}$ and the diastolic between 50 and 70 . After the first few hours, the patient was somewhat restless and slept intermittently; his color was good at all times. Sweating was profuse during induction and the first 4 hours of the fever. After the sixth hour visible sweating ceased. Beginning with the eighth hour he complained of abdominal pain, localized about the umbilicus. This varied in intensity but gradually became more severe until fever was discontinued. After the twenty-fourth hour, he complained of mild pain over the precordium. This was hard to evaluate because of the patient's apprehensiveness.

Patient $W$. $D$., female, age 31 . Induction of fever was begun at 8:30 a.m., August 24, 1936. After $100 \mathrm{~min}$ utes the temperature had reached $39.5^{\circ} \mathrm{C}$., where it was kept for 48 hours. The patient was cheerful, cooperative, and not in the least upset during the treatment. She slept a good part of the time. At all times sweating was much less than was observed in the other patients. Her color was good throughout. The systolic blood 
TABLE I

Balance data on Patient F. P. (Hospital No. 76562) June 16 to 23, 1935*

\begin{tabular}{|c|c|c|c|c|c|c|c|c|c|}
\hline \multirow{2}{*}{ Day } & \multirow{2}{*}{$\begin{array}{l}\text { Weight } \\
\text { change }\end{array}$} & \multicolumn{2}{|c|}{ Sodium } & \multicolumn{2}{|c|}{ Potassium } & \multicolumn{2}{|c|}{ Chloride } & \multicolumn{2}{|c|}{ Nitrogen } \\
\hline & & Intake & Balance & Intake & Balance & Intake & Balance & Intake & Balance \\
\hline $4\left\{\begin{array}{c}1 \\
2 \\
3 \\
6 \text { a.m. }-3 \text { p.m. } \\
3 \text { p.m. }-6 \text { a.m. } \\
5 \\
6 \\
7\end{array}\right.$ & $\begin{array}{r}\text { grams } \\
-460 \\
-180 \\
-30 \\
-1370 \\
\\
+710 \\
+580 \\
+50 \\
+80\end{array}$ & $\begin{array}{l}m . e q . \\
95.6 \\
94.4 \\
95.6 \\
47.9 \\
47.9 \\
95.8 \\
95.8 \\
95.4\end{array}$ & $\begin{array}{l}\text { m.eq. } \\
-37.3 \\
+15.3 \\
+17.7 \\
-104.3 \\
+46.9 \\
+91.1 \\
+74.0 \\
+32.1\end{array}$ & $\begin{array}{l}m . e q . \\
66.8 \\
75.0 \\
77.6 \\
74.0 \\
\\
71.3 \\
74.6 \\
74.6\end{array}$ & $\begin{array}{r}\text { m.eq. } \\
-26.2 \\
+00.3 \\
-11.2 \\
-5.7 \\
+20.0 \\
+1.2 \\
-13.3\end{array}$ & $\begin{array}{l}\text { m.eq. } \\
98.9 \\
98.9 \\
98.9 \\
48.7 \\
48.7 \\
97.5 \\
97.5 \\
97.5\end{array}$ & $\begin{array}{r}\text { m.eq. } \\
-59.3 \\
+8.7 \\
+21.0 \\
-128.3 \\
+47.4 \\
+88.0 \\
+55.0 \\
+24.5\end{array}$ & $\begin{array}{l}\text { grams } \\
8.71 \\
8.92 \\
9.23 \\
\\
8.95 \\
\\
8.93 \\
8.83 \\
8.76\end{array}$ & $\begin{array}{l}\text { grams } \\
-1.51 \\
-1.39 \\
-1.77 \\
-0.64 \\
-3.61 \\
-1.64 \\
-1.25\end{array}$ \\
\hline
\end{tabular}

* Artificial fever 4th day. Induction time 80 minutes, temperature maintained at $40.5^{\circ} \mathrm{C}$. for 4 hours, recovery time 1 hour. Initial weight $1 \mathrm{st}$ day $54.560 \mathrm{kgm}$. Liquid diet 1300 calories.

pressure varied from 88 to $100 \mathrm{~mm}$. $\mathrm{Hg}$, the diastolic from values too low to record to $70 \mathrm{~mm}$. $\mathrm{Hg}$. The pulse rate varied between 115 and 135 per minute during the first 8 hours of fever, thereafter it gradually became somewhat slower and during the last 20 hours it was between 100 and 110 per minute.

\section{PRESENTATION OF DATA}

The condensed balance data are recorded in $\mathrm{Ta}$ bles I to IV. The fecal excretions of nitrogen, potassium, sodium, and chloride were included. The latter two were almost negligible.
The losses of electrolytes during the fever periods are summarized in Table V. Estimations are given of the fractions of total body electrolytes which these losses represent. It was assumed that extracellular water was equal to 20 per cent of the weight of the body at the beginning of fever and that sodium and chloride were confined to this compartment in concentrations which could be derived from analysis of serum. The percentage of water in serum was found directly in $\mathrm{Pa}$ tients F. P. and L. H. ; in Patients S. B. and W. D.

TABLE II

Balance data on Patient L. H. (Hospital No. 100882) A pril 6 to 29, 1935*

\begin{tabular}{|c|c|c|c|c|c|c|c|c|c|}
\hline \multirow{2}{*}{ Day } & \multirow{2}{*}{$\begin{array}{l}\text { Weight } \\
\text { change }\end{array}$} & \multicolumn{2}{|c|}{ Sodium } & \multicolumn{2}{|c|}{ Potassium } & \multicolumn{2}{|c|}{ Chloride } & \multicolumn{2}{|c|}{ Nitrogen } \\
\hline & & Intake & Balance & Intake & Balance & Intake & Balance & Intake & Balance \\
\hline $\begin{array}{c}1-10 \\
11 \\
12 \\
13\left\{\begin{array}{c}7: 30 \text { a.m. }-5 \text { p.m. } \\
5 \text { p.m. }-7: 30 \text { a.m. } \\
14 \\
15 \\
16 \\
17 \\
18 \\
19 \\
20 \\
21 \\
22 \\
23 \\
24\end{array}\right.\end{array}$ & $\begin{array}{r}\text { grams } \\
0 \\
-380 \\
+410 \\
-850 \\
+550 \\
+440 \\
0 \\
-180 \\
-20 \\
-40 \\
-100 \\
+10 \\
+60 \\
-60 \\
-140 \\
-40\end{array}$ & $\begin{array}{r}\text { m.eq. } \\
111.7 \\
111.3 \\
111.3 \\
27.8 \\
\\
83.5 \\
111.3 \\
111.3 \\
111.3 \\
111.3 \\
111.3 \\
111.3 \\
111.3 \\
111.3 \\
111.3 \\
111.3 \\
111.3\end{array}$ & $\begin{array}{r}\text { m.eq. } \\
+1.8 \\
-39.5 \\
+15.9 \\
-141.3 \\
+83.0 \\
+70.2 \\
+29.5 \\
+5.1 \\
-0.9 \\
+1.2 \\
+9.6 \\
+5.7 \\
+8.3 \\
-8.9 \\
-0.9 \\
-0.1\end{array}$ & $\begin{array}{c}\text { m.eq. } \\
110.5 \\
109.7 \\
109.7 \\
109.7 \\
109.7 \\
109.7 \\
109.7 \\
109.7 \\
109.7 \\
109.7 \\
109.7 \\
109.7 \\
109.7 \\
109.7 \\
109.7\end{array}$ & $\begin{array}{r}\text { m.eq. } \\
-1.1 \\
-7.9 \\
-9.6 \\
-5.3 \\
+13.7 \\
-2.8 \\
-0.1 \\
+3.3 \\
-5.8 \\
+10.6 \\
+6.4 \\
+2.1 \\
+0.2 \\
-15.1 \\
-0.6\end{array}$ & $\begin{array}{r}\text { m.eq. } \\
117.7 \\
116.8 \\
116.8 \\
29.3 \\
\\
87.6 \\
116.8 \\
116.8 \\
116.8 \\
116.8 \\
116.8 \\
116.8 \\
116.8 \\
116.8 \\
116.8 \\
116.8 \\
116.8\end{array}$ & $\begin{array}{r}\text { m.eq. } \\
+2.7 \\
-9.5 \\
+12.1 \\
-102.0 \\
+87.1 \\
+71.8 \\
+20.0 \\
+4.7 \\
-6.9 \\
-2.6 \\
+6.2 \\
+5.8 \\
+7.2 \\
-6.5 \\
-0.6 \\
+0.6\end{array}$ & $\begin{array}{l}\text { grams } \\
12.99 \\
12.67 \\
12.67 \\
12.67 \\
12.67 \\
12.67 \\
12.67 \\
12.67 \\
12.67 \\
12.67 \\
12.67 \\
12.67 \\
12.67 \\
12.67 \\
12.67\end{array}$ & $\begin{array}{c}\text { grams } \\
-0.15 \\
-0.34 \\
-0.34 \\
+1.14 \\
-2.09 \\
+0.16 \\
+0.12 \\
-0.50 \\
+0.12 \\
-0.50 \\
+0.27 \\
-0.16 \\
-0.51 \\
-0.81 \\
-0.57\end{array}$ \\
\hline
\end{tabular}

- Artificial fever 13th day. Induction time 3 hours. Temperature maintained at $40.5^{\circ} \mathrm{C}$. for 4 hours. Recovery time $1 \frac{1}{2}$ hours. Initial weight first day $53.150 \mathrm{kgm}$. Liquid diet 1875 calories. Skin loss included in calculation of balances on Days 11 and 13 only. 
TABLE III

Balance data on Patient S. B. (Hospital No. 89130) August 5 to 20, 1936 *

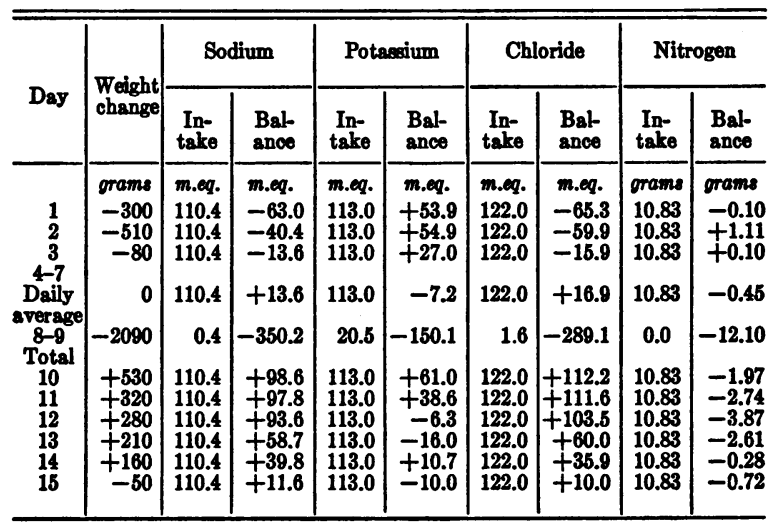

* Artificial fever-Days 8 and 9: Induction time 1 hour 10 minutes, temperature maintained at $39.5^{\circ} \mathrm{C}$. for 34 hours, recovery time 1 hour 10 minutes. Initial weight, 1st day $62.340 \mathrm{kgm}$. Liquid diet 2000 calories. (Skin losses, as recorded in Table $\mathrm{V}$, were included in the calculations of the balances for both the control and febrile days.)

it was calculated from the serum protein concentration by use of the formula developed by Eisenman, Mackenzie, and Peters (21). To obtain the concentrations of sodium and chloride in extracellular water, the values for serum water were corrected for the Gibbs-Donnan effect (22) by multiplying by the factors 0.95 and $1 / 0.95$ respectively. Fifty per cent of the body weight was taken as the weight of intracellular water, and the potassium concentration therein was considered to be approximately equal to the sodium in extracellular fluid. The values for sodium, potassium, and chloride thus obtained were used in constructing Figures 1 and 2 which represent the daily changes in weight and electrolyte balances of Patients F. P. and S. B.

It will be noticed that losses of sodium and chloride through the skin varied from 6.5 to 19 per cent of the amount calculated to be in the extracellular fluid at the beginning of fever treatment (Table V).

It is well known that the ability to sweat varies considerably in different individuals. This is illustrated by the electrolyte losses of these patients. Patient W. D. was exposed to the same temperature as Patient S. B., but for 8 hours longer. In spite of this the electrolyte loss of the former by way of the sweat was only a fraction of the loss of the latter. This difference was reflected in the clinical condition of the two patients. Patient W. D. tolerated the fever in comfort while Patient S. B. became irritable and complained of pains in the legs, abdomen, and chest.

Similar but less marked differences were found in the electrolyte losses of Patients L. H. and F. P. Because of more prolonged induction and recovery periods, the temperature of the former was elevated above normal for over 2 hours longer than that of Patient F. P. Nevertheless, the loss through the skin was greater in the latter (Table V).

The amount of salt S. B. excreted in the urine was quite small, and previous experience leads us to believe that this must have been excreted during the first few hours. Patient W. D., on the other hand, excreted slightly more in the urine than was lost through the skin in spite of practically no intake. The total loss of electrolyte from the body of these individuals, was, therefore, not dependent solely on skin loss (see Tables III, IV, and $\mathrm{V}$ ).

The electrolyte intakes of Patients F. P. and L. H. were kept the same during fever as on control days but were insufficient to offset the deficit of salt which developed because of sweating ( $\mathrm{Ta}$ bles I and II).

Correlation between electrolyte and weight loss. In each case except F. P., the extracellular water

TABLE IV

Balance data on Patient W. D. (Hospital No. 118263) August 16 to 30, 1936*

\begin{tabular}{|c|c|c|c|c|c|c|c|c|c|}
\hline \multirow{2}{*}{ Day } & \multirow{2}{*}{$\begin{array}{l}\text { Weight } \\
\text { change }\end{array}$} & \multicolumn{2}{|c|}{ Sodium } & \multicolumn{2}{|c|}{ Potacaium } & \multicolumn{2}{|c|}{ Chloride } & \multicolumn{2}{|c|}{ Nitrogen } \\
\hline & & $\underset{\text { take }}{\text { In- }}$ & $\begin{array}{l}\text { Bal- } \\
\text { ance }\end{array}$ & In- & $\begin{array}{l}\text { Bat } \\
\text { ance }\end{array}$ & In- & $\begin{array}{l}\text { Bat } \\
\text { ance }\end{array}$ & In- & $\begin{array}{l}\text { Bal- } \\
\text { ance }\end{array}$ \\
\hline $\begin{array}{r}1 \\
2 \\
3 \\
4 \\
5 \\
6 \\
7 \\
7 \\
8 \\
9+10\end{array}$ & $\begin{array}{l}\text { grams } \\
-210 \\
-100 \\
-210 \\
+60 \\
+160 \\
-10 \\
+410 \\
-410 \\
-860\end{array}$ & $\begin{array}{r}m . e q . \\
43.2 \\
43.2 \\
43.2 \\
43.2 \\
43.2 \\
43.2 \\
214.0 \\
214.0 \\
1.0\end{array}$ & $\begin{array}{r}m .69 . \\
-37.8 \\
-7.1 \\
-5.4 \\
+8.8 \\
+4.9 \\
+70.8 \\
-14.0 \\
-168.0\end{array}$ & $\begin{array}{l}m . e q . \\
70.1 \\
70.1 \\
68.3 \\
68.3 \\
68.3 \\
68.3 \\
68.3 \\
68.3 \\
15.8\end{array}$ & $\begin{array}{r}\text { m.eq. } \\
-2.1 \\
+6.1 \\
-10.8 \\
+13.0 \\
+2.7 \\
-14.2 \\
-21.4 \\
-68.6\end{array}$ & $\begin{array}{r}m . e q . \\
48.3 \\
48.3 \\
47.9 \\
47.9 \\
47.9 \\
47.9 \\
218.8 \\
218.8 \\
3.2\end{array}$ & $\begin{array}{r}m .0 q . \\
-26.8 \\
+0.4 \\
-3.8 \\
+9.4 \\
+11.4 \\
+5.7 \\
+82.2 \\
-24.4 \\
-157.5\end{array}$ & $\begin{array}{c}\text { grams } \\
7.71 \\
7.71 \\
\mathbf{7 . 7 1} \\
\mathbf{7 . 7 1} \\
\mathbf{7 . 7 1} \\
\mathbf{7 . 7 1} \\
\mathbf{7 . 7 1} \\
\mathbf{7 . 7 1} \\
\mathbf{0 . 2 4}\end{array}$ & $\begin{array}{c}\text { grams } \\
-1.04 \\
-0.56 \\
-1.75 \\
-0.20 \\
-0.80 \\
-1.21 \\
-1.53 \\
-1.66 \\
-11.61\end{array}$ \\
\hline $\begin{array}{l}11 \\
12 \\
13 \\
14 \\
15\end{array}$ & $\begin{array}{r}+20 \\
+90 \\
+10 \\
+830 \\
-400\end{array}$ & $\begin{array}{r}43.2 \\
43.2 \\
43.2 \\
214.0 \\
43.2\end{array}$ & $\begin{array}{r}+34.0 \\
+33.6 \\
+28.6 \\
+112.7 \\
-58.0\end{array}$ & $\begin{array}{l}68.3 \\
68.3 \\
68.3 \\
68.3 \\
68.3 \\
68.3\end{array}$ & $\begin{array}{r}+42.1 \\
+7.2 \\
+2.5 \\
+4.0 \\
+6.1\end{array}$ & $\begin{array}{r}47.9 \\
47.9 \\
47.9 \\
218.8 \\
47.9\end{array}$ & $\begin{array}{r}+31.7 \\
+31.5 \\
+28.8 \\
+125.9 \\
-49.0\end{array}$ & $\begin{array}{l}\mathbf{7 . 7 1} \\
\mathbf{7 . 7 1} \\
\mathbf{7 . 7 1} \\
\mathbf{7 . 7 1} \\
\mathbf{7 . 7 1}\end{array}$ & $\begin{array}{l}+1.00 \\
-2.24 \\
-1.54 \\
-1.12 \\
-0.43\end{array}$ \\
\hline
\end{tabular}

* Artificial fever-Days 9 and 10: Induction time 1 hour and 40 minutes, temperature maintained at $37.5^{\circ} \mathrm{C}$. for 48 hours, recovery time 1 hour. Initial weight 1st day $45.030 \mathrm{kgm}$. Liquid diet 1550 calories. (Skin losses, as recorded in Table $\mathrm{V}$, were included in the calculations of the balances for both control and febrile days.) 
TABLE $v$

Electrolytes during fever

\begin{tabular}{|c|c|c|c|c|c|c|c|c|c|c|}
\hline \multirow{3}{*}{$\begin{array}{l}\text { Patient } \\
\text { F. P. }\end{array}$} & \multirow{3}{*}{$\begin{array}{l}\text { Electrolyte } \\
\\
\begin{array}{l}\text { Sodium } \\
\text { Chloride } \\
\text { Potassium }\end{array}\end{array}$} & \multicolumn{2}{|c|}{ Control period } & \multicolumn{7}{|c|}{ Fever period } \\
\hline & & \multirow{2}{*}{\begin{tabular}{|c|}
$\begin{array}{c}\text { Rectal tem- } \\
\text { perature }\end{array}$ \\
${ }^{\circ} \mathrm{C}$. \\
$36.5-37$
\end{tabular}} & \multirow{2}{*}{$\begin{array}{c}\begin{array}{c}\text { Skin } \\
\text { loss }\end{array} \\
\begin{array}{c}\text { grams } \\
\text { per day }\end{array}\end{array}$} & \multirow{2}{*}{$\begin{array}{c}\text { Rectal tem- } \\
\text { perature }\end{array}$} & \multirow{2}{*}{$\begin{array}{c}\begin{array}{c}\text { Duration } \\
\text { of fever }\end{array} \\
\text { hours } \\
4\end{array}$} & \multicolumn{2}{|c|}{ Skin loss } & \multirow{2}{*}{$\begin{array}{l}\begin{array}{c}\text { Net } \\
\text { loss }\end{array} \\
\text { m.eq. } \\
104.3 \\
128.0\end{array}$} & \multirow{2}{*}{\begin{tabular}{|c}
$\begin{array}{c}\text { Skin loss } \\
\text { as per cent } \\
\text { of amount } \\
\text { in body }\end{array}$ \\
\\
\\
\\
8.0 \\
13.0 \\
$<1.0$
\end{tabular}} & \multirow{2}{*}{$\begin{array}{c}\begin{array}{c}\text { Net loss } \\
\text { as per cent } \\
\text { of amount } \\
\text { in body }\end{array} \\
\\
\\
7.0 \\
11.0\end{array}$} \\
\hline & & & & & & $\begin{array}{l}\text { grams } \\
\\
2.992 \\
5.476 \\
0.361\end{array}$ & $\begin{array}{r}\text { m.eq. } \\
\\
130.0 \\
154.0 \\
9.3\end{array}$ & & & \\
\hline L. H. & $\begin{array}{l}\text { Sodium } \\
\text { Chloride } \\
\text { Potassium }\end{array}$ & $36.5-37$ & $\begin{array}{l}0.234 \\
0.281 \\
0.373\end{array}$ & 40.5 & 4 & $\begin{array}{l}2.510 \\
3.525 \\
0.687\end{array}$ & $\begin{array}{r}109.1 \\
99.4 \\
17.6\end{array}$ & $\begin{array}{l}141.3 \\
102.0\end{array}$ & $\begin{array}{r}7.0 \\
8.5 \\
<1.0\end{array}$ & $\begin{array}{l}8.5 \\
8.5\end{array}$ \\
\hline S. B. & $\begin{array}{l}\text { Sodium } \\
\text { Chloride } \\
\text { Potassium }\end{array}$ & $36.5-37^{*}$ & $\begin{array}{l}0.237 \\
0.217 \\
0.220\end{array}$ & 39.5 & 36 & $\begin{array}{l}7.611 \\
9.438 \\
2.069\end{array}$ & $\begin{array}{r}330.9 \\
265.9 \\
51.5\end{array}$ & $\begin{array}{l}350.2 \\
289.1 \\
150.1\end{array}$ & $\begin{array}{r}18.6 \\
19.0 \\
1.0\end{array}$ & $\begin{array}{r}19.8 \\
22.0 \\
3.0\end{array}$ \\
\hline W. D. & $\begin{array}{l}\text { Sodium } \\
\text { Chloride } \\
\text { Potassium }\end{array}$ & $36.5-37 \dagger$ & $\begin{array}{l}0.069 \\
0.083 \\
0.123\end{array}$ & 39.5 & 48 & $\begin{array}{l}1.914 \\
2.505 \\
1.141\end{array}$ & $\begin{array}{l}83.0 \\
70.6 \\
29.2\end{array}$ & $\begin{array}{r}168.0 \\
157.5 \\
68.6\end{array}$ & $\begin{array}{r}6.6 \\
6.7 \\
<1.0\end{array}$ & $\begin{array}{r}13.4 \\
15.0 \\
2.0\end{array}$ \\
\hline
\end{tabular}

- Maximum room temperature: Dry bulb $78^{\circ} \mathrm{F}$. Wet bulb $68^{\circ} \mathrm{F}$.

$\dagger$ Maximum room temperature: Dry bulb $78^{\circ} \mathrm{F}$. Wet bulb $64^{\circ} \mathrm{F}$.

loss, if calculated from the losses of sodium or chloride and their concentration in the blood serum at the beginning of treatment, amounted to more than the loss of weight (Figure 1). If an estimate of the loss of potassium from intracellular water is included also, the expected loss of water is far in excess of the actual decrease in weight. In the case of S. B., for example (Figure 1), the combined negative balances of sodium and potassium would account for a loss of 3 kilos, while only 2 kilos were lost. This seeming discrepancy is accounted for by the gradual dilution of the electrolyte remaining in the body (Table VII). In Patient F. P. the actual weight loss was greater than that calculated for the electrolyte loss, while the concentration of sodium and chloride in serum water increased slightly (Figure 2 and Table VII). The comparatively limited fluid intake of this patient appears to explain the difference in her response.

Several days were required to replace the deficit of sodium and chloride. In S. B. the retention lasted for 5 days. In each case, positive balances were greater than the amount lost during the days of fever (Figures 1 and 2). This may be at- tributed to 1 of 3 causes, namely, analytical errors, greater electrolyte loss through the skin after fever than before, or increased storage after fever. Considerable experience with the methods which were employed leads us to conclude that analytical errors of this magnitude were unlikely. We have no direct evidence for or against either of the other possibilities. A labile vasomotor system after febrile illnesses is observed clinically. Manery et al. have found connective tissue to be rich in sodium and chloride (23); it is possible that the increased mobility of joints after fever may have favored its retention there.

Changes in the blood and body fiuids. The determinations of hematocrit, hemoglobin, serum proteins, and serum solids all point to moderate dehydration of the blood in 3 of the patients (Table VI). This was most pronounced in F. P., and, as previously stated, seems to have been due to a rather low intake of water during the period when her secretion of sweat was at a maximum. In the fourth patient, W. D., there was no evidence of hemoconcentration, probably because of a smaller and less rapid loss of water through the skin (Table VIII). In no case did 

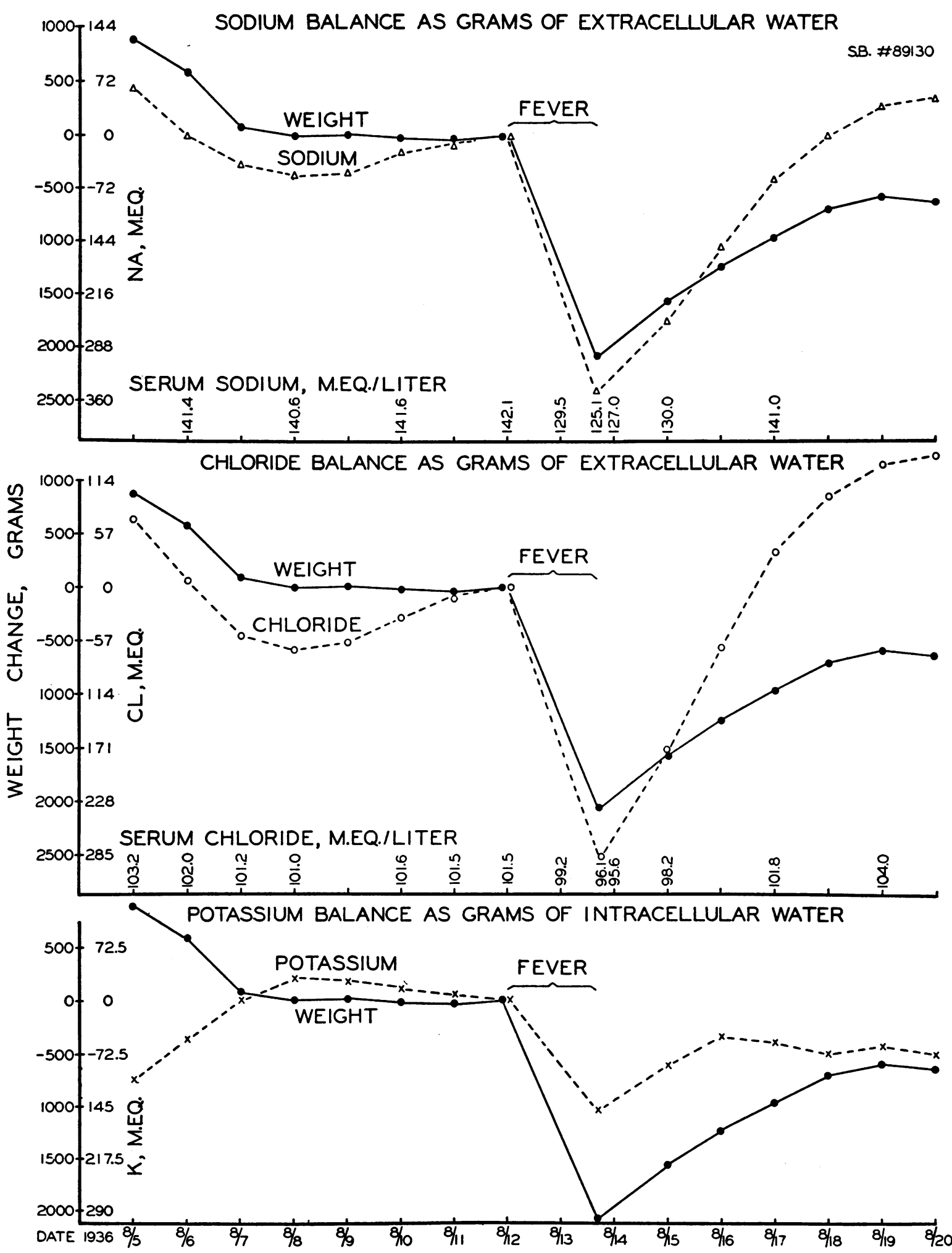

Fig. 1. Weight and Electrolyte Balances in Patient S. B.

Sodium and chloride are plotted to represent extracellular water, potassium to represent intracellular water. 


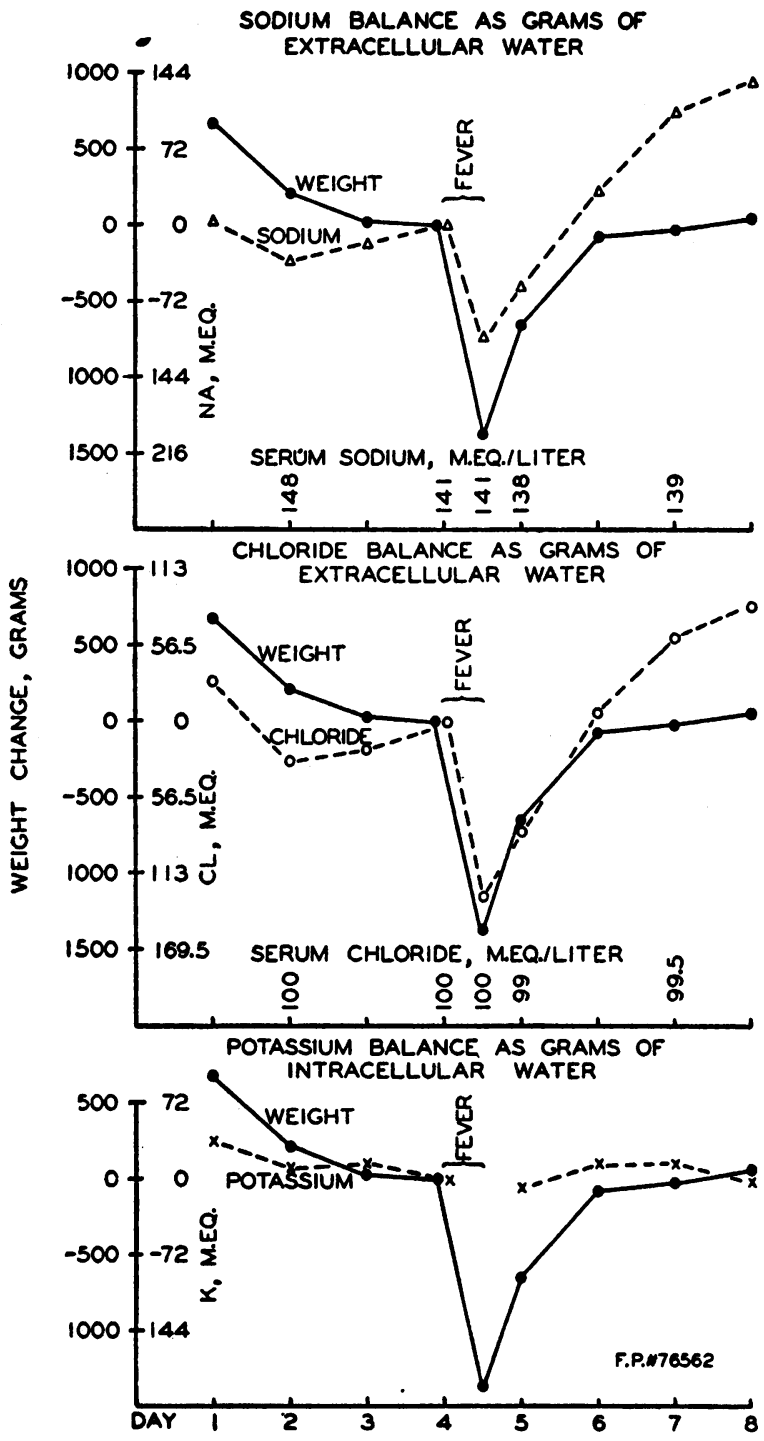

Fig. 2. Weight and Electrolyte Balances in Patient F. P.

Sodium and chloride balances are plotted to represent extracellular water, potassium to represent intracellular water.

the anhydremia approach that found by Talbott $(3,4)$ in studies of heat cramps.

There were 3 instances in which the amount of sodium and chloride lost was sufficient to cause a definite reduction of the concentration of these substances in the blood serum (Tables VI and VII). The $\mathrm{CO}_{2}$ content of the serum decreased also, but the decrease of sodium was greater in each case than the combined decreases of chloride and carbon dioxide. This was to be expected
TABLE VI

Blood changes associated with artificial fever

\begin{tabular}{|c|c|c|c|c|c|c|c|c|c|}
\hline \multirow{2}{*}{$\begin{array}{l}\text { Par- } \\
\text { tient }\end{array}$} & \multirow{2}{*}{ Day } & \multirow{2}{*}{ Remarks } & \multicolumn{5}{|c|}{ Serum } & \multicolumn{2}{|c|}{ Whole blood } \\
\hline & & & $\begin{array}{c}\text { So- } \\
\text { dium }\end{array}$ & $\begin{array}{l}\text { Chlo- } \\
\text { ride }\end{array}$ & $\mid \begin{array}{c}\mathrm{CO}_{2} \\
\text { content }\end{array}$ & $\begin{array}{l}\text { Sol- } \\
\text { ids }\end{array}$ & $\begin{array}{l}\text { Pro- } \\
\text { tein }\end{array}$ & $\begin{array}{l}\text { Hemo- } \\
\text { globin }\end{array}$ & Hema- \\
\hline F. $P$. & $\begin{array}{l}2 \\
4 \\
5 \\
7\end{array}$ & $\begin{array}{l}\text { Control } \\
\text { Before fever } \\
\text { After fever }\end{array}$ & $\begin{array}{l}\text { m.eq. } \\
\text { per } \\
\text { liter } \\
148.0 \\
141.0 \\
141.0 \\
138.0 \\
138.0\end{array}$ & $\begin{array}{c}\text { m.eq. } \\
\text { per } \\
\text { liter } \\
100.0 \\
100.0 \\
100.0 \\
99.0 \\
99.5\end{array}$ & $\underset{\substack{\text { per } \\
\text { liter }}}{\text { lis. }}$ & $\begin{array}{c}\text { per } \\
\text { cent by } \\
\text { weight } \\
9.7 \\
9.6 \\
11.3 \\
9.6 \\
8.9\end{array}$ & $\begin{array}{l}\text { per } \\
\text { cent }\end{array}$ & $\begin{array}{c}\text { grams } \\
\text { per } \\
100 \mathrm{ml} . \\
12.0 \\
14.0 \\
11.67 \\
11.46\end{array}$ & $\begin{array}{l}\text { per } \\
\text { cent } \\
40.2 \\
41.0 \\
45.0 \\
38.2 \\
37.4\end{array}$ \\
\hline L. $\mathbf{H}$. & $\begin{array}{r}3 \\
7 \\
10 \\
13 \\
14 \\
20\end{array}$ & $\begin{array}{l}\text { Control } \\
\text { Control } \\
\text { Control } \\
\text { Before fever } \\
\text { After fever }\end{array}$ & & \begin{tabular}{|r|r|}
98.5 \\
102.2 \\
\\
101.0 \\
88.5 \\
88.8 \\
98.7
\end{tabular} & $\begin{array}{l}31.8 \\
30.8 \\
29.5 \\
24.8 \\
28.6 \\
29.4\end{array}$ & $\begin{array}{l}8.8 \\
8.5 \\
8.8 \\
9.2 \\
8.4 \\
8.8\end{array}$ & $\begin{array}{l}6.3 \\
6.3 \\
6.6 \\
6.2 \\
6.1 \\
6.1\end{array}$ & $\begin{array}{l}14.49 \\
14.57 \\
14.85 \\
15.90 \\
14.61\end{array}$ & $\begin{array}{l}42.7 \\
45.7 \\
47.8 \\
41.8\end{array}$ \\
\hline B. B. & $\begin{array}{c}1 \\
2 \\
4 \\
6 \\
7 \\
8+9 \\
10 \\
11 \\
13 \\
15\end{array}$ & $\begin{array}{l}\text { Control } \\
\text { Control } \\
\text { Control } \\
\text { Control } \\
\text { Control } \\
\text { Bufore ferer } \\
\text { During fever } \\
\text { After fever }\end{array}$ & $\begin{array}{l}141.4 \\
141.0 \\
141.6 \\
142.0 \\
142.1 \\
129.5 \\
125.1 \\
127.0 \\
130.0 \\
141.0\end{array}$ & $\begin{array}{r}103.2 \\
102.0 \\
101.0 \\
101.6 \\
101.5 \\
101.5 \\
99.2 \\
98.1 \\
85.6 \\
88.2 \\
101.8 \\
104.0\end{array}$ & $\begin{array}{l}28.5 \\
30.4 \\
30.5 \\
\mathbf{8 0 . 7} \\
30.9 \\
\mathbf{3 0 . 7} \\
25.3 \\
24.9 \\
27.9 \\
28.5 \\
28.1\end{array}$ & & $\begin{array}{l}6.44 \\
7.14 \\
7.00\end{array}$ & & $\begin{array}{l}44.4 \\
44.0 \\
44.0 \\
48.7 \\
44.5 \\
45.0 \\
39.4 \\
38.3\end{array}$ \\
\hline W. D. & $\begin{array}{r}2 \\
4 \\
9 \\
10 \\
11 \\
12 \\
13 \\
15\end{array}$ & $\begin{array}{l}\text { Control } \\
\text { Control } \\
\text { Before fever } \\
\text { After fever }\end{array}$ & $\begin{array}{l}136.0 \\
135.0 \\
188.0 \\
130.0 \\
132.0 \\
134.0 \\
137.0 \\
135.0\end{array}$ & \begin{tabular}{|r|r|}
101.2 & 104.8 \\
10.5 & 104.5 \\
103.3 & 90.4 \\
100.3 & 10.5 \\
101.5 & 103.2
\end{tabular} & $\begin{array}{l}25.1 \\
26.4 \\
24.5 \\
26.6 \\
\\
28.4\end{array}$ & & $\begin{array}{l}6.70 \\
6.50 \\
6.48 \\
6.50\end{array}$ & & $\begin{array}{l}38.0 \\
39.1 \\
36.0 \\
36.0 \\
34.0 \\
35.0\end{array}$ \\
\hline
\end{tabular}

TABLE VII

Changes in concentration of electrolytes in serum water associated with artificial fever

\begin{tabular}{|c|c|c|c|c|c|}
\hline \multirow{2}{*}{ Patient } & \multirow{2}{*}{ Remarks } & \multirow{2}{*}{$\begin{array}{l}\text { Water } \\
\text { in } \\
\text { serum }\end{array}$} & \multicolumn{3}{|c|}{$\begin{array}{l}\text { Concentration in } \\
\text { serum water }\end{array}$} \\
\hline & & & $\mathrm{Na}$ & $\mathrm{Cl}$ & $\mathrm{CO}_{2}$ \\
\hline F. P. & $\begin{array}{l}\text { Before fever } \\
\text { After fever }\end{array}$ & $\begin{array}{l}\text { per cent } \\
\text { by } \\
\text { oolume } \\
92.9 \\
91.2\end{array}$ & $\begin{array}{c}\text { m.eq. } \\
\text { per } \\
\text { liter } \\
151.7 \\
154.6\end{array}$ & $\begin{array}{l}\text { m.eq. } \\
\text { per } \\
\text { tiler } \\
107.6 \\
109.6\end{array}$ & $\begin{array}{c}\text { m.eq. } \\
\text { per } \\
\text { liter }\end{array}$ \\
\hline L. $\mathbf{H}$. & $\begin{array}{l}\text { Before fever } \\
\text { After fever }\end{array}$ & $\begin{array}{l}93.8 \\
93.6\end{array}$ & & $\begin{array}{l}106.5 \\
105.2\end{array}$ & $\begin{array}{l}31.4 \\
26.5\end{array}$ \\
\hline S. B. & $\begin{array}{l}\text { Before fever } \\
\text { After } 24 \text { hours of fever } \\
\text { After } 36 \text { hours of fever }\end{array}$ & $\begin{array}{l}93.7 \\
93.2 \\
93.2\end{array}$ & $\begin{array}{l}154.7 \\
138.9 \\
134.2\end{array}$ & $\begin{array}{l}108.3 \\
106.4 \\
103.1\end{array}$ & $\begin{array}{l}32.7 \\
27.1 \\
26.7\end{array}$ \\
\hline W. D. & $\begin{array}{l}\text { Before fever } \\
\text { After } 24 \text { hours of fever } \\
\text { After } 48 \text { hours of fever }\end{array}$ & $\begin{array}{l}93.7 \\
93.7 \\
93.6\end{array}$ & $\begin{array}{l}147.0 \\
139.0 \\
141.0\end{array}$ & $\begin{array}{l}111.8 \\
110.4 \\
106.0\end{array}$ & $\begin{array}{l}28.2 \\
26.2 \\
28.4\end{array}$ \\
\hline
\end{tabular}

since the net losses of sodium were considerably in excess of the net losses of chloride (see fever days Table V).

Of the 2 subjects with mild symptoms resembling heat cramps, 1 (F. P.) concentrated serum 
TABLE VIII

Losses of water through skin and lungs

\begin{tabular}{|c|c|c|c|c|c|}
\hline \multirow[b]{2}{*}{ Patient } & \multicolumn{2}{|c|}{ Average normal day } & \multicolumn{3}{|c|}{ Day or days of fever } \\
\hline & Intake & $\begin{array}{c}\text { Skin } \\
\text { and } \\
\text { lungs }\end{array}$ & Intake & $\begin{array}{l}\text { Skin } \\
\text { and } \\
\text { lungs }\end{array}$ & $\begin{array}{l}\text { Increase } \\
\text { over nor- } \\
\text { mal day }\end{array}$ \\
\hline 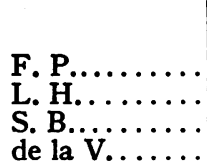 & $\begin{array}{c}\text { grams } \\
\text { per day } \\
3550 \\
3770 \\
3288 \\
2816\end{array}$ & $\begin{array}{c}\text { grams } \\
\text { per day } \\
860 \\
1135 \\
1180 \\
882\end{array}$ & $\begin{array}{c}\text { grams } \\
\text { per day } \\
3550 \\
4770 \\
4543 \\
4683\end{array}$ & 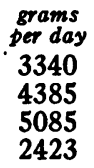 & $\begin{array}{c}\text { grams } \\
\text { per day } \\
2480 \\
3250 \\
3905 \\
1541\end{array}$ \\
\hline
\end{tabular}

electrolytes; in the other (S. B.) the loss of salt led to a decrease in concentration. A considerable disturbance of water balance occurred in each subject and was probably a more potent factor in the causation of symptoms than the change in concentration of electrolytes.

Composition of sweat. The concentration of electrolytes in sweat is known to vary considerably (1). Wide variations in the proportions of different ions to one another as found in Table $\mathrm{V}$ are in accord with the work of McSwiney (24), who found the $\mathrm{pH}$ of sweat to vary from 5.1 to 7.76. Fishberg and Bierman (25) found large amounts of lactic acid in the sweat during hyperthermia. This may have been responsible for the excess of fixed base over chloride lost through the skin by 3 of our patients.

By using the data in Tables V and VIII and assuming a loss of 400 to $500 \mathrm{ml}$. of water from the lungs, one can derive an approximation of the average concentration of the sweat on the days of fever. The level of sodium ranged from 20 m.eq. per liter in W. D. to $45 \mathrm{~m}$.eq. per liter in F. P.; the range of chloride was from $18 \mathrm{~m} . e q$. in the former to $53 \mathrm{~m} . e q$. in the latter. The concentration of potassium varied between 3 and 7 m.eq. per liter. Dill (1) has reviewed factors influencing the ability to form concentrated or dilute sweats. Among these is mentioned the possibility that a more dilute sweat is secreted when the level of salt in the blood falls below normal. The converse of this may have been true in F. P., who was the only subject to increase the concentration of electrolyte in serum water during fever (Table VII).

Comment. Although the conditions which led to the losses of variable amounts of water and electrolytes in the 4 subjects differed from one another, there was sufficient similarity between the duration and height of fever in F. P. and L. H. and in S. B. and W. D. to permit comparison and to bring out clearly the marked individual differences in their responses. The first two patients had short fevers and their net salt deficits were of the order of 10 per cent of the amount computed to have been present in the body at the beginning of treatment. Both tolerated the fever well. Net salt deficits in the 2 patients who were treated for longer periods were greater, but were hardly as large as one might have expected on the basis of the shorter fevers. Two explanations may account for the latter observation; (a) a lower body temperature was maintained during the longer fevers, (b) there was a fairly definite tendency for sweating to decrease when fever was prolonged beyond 3 or 4 hours.

There can be but little question that loss of extracellular fluid represented the chief and most important contribution from the body water. The reservoirs of extracellular water which were drawn upon are not known. Probably all of the tissues contributed water and salt, but it is unlikely that the quantities of fluid liberated were strictly proportional to the initial amount present in the tissue. Selective dehydration if it affected the blood plasma more than other tissues, as appeared to be the case in some of Gibson's subjects, might prove an embarrassment to the circulation. That selective dehydration may take place is apparent from the acute terminal experiments of Yannet and Darrow (26) who found that hyperthermia caused dehydration of the cells of the the brains of cats. The reactions of this particular animal and man to high temperatures are hardly comparable. Man sweats profusely, the cat almost none (27), so that the possibility of loss of water is much greater in the former. Other tissues beside the brain and blood must be affected. Of these the liver is certainly under suspicion for a low grade of jaundice is one of the complications of fever therapy (28).

Our experiments give little information with respect to the effect of hyperthermia on cell water. The potassium and nitrogen balances of the patients who were treated with 4-hour fevers and received their usual diets on the day of treatment were nearly the same as on control days. Appreciable losses of potassium and nitrogen were 
encountered during the 36 and 48-hour fevers but were probably associated with catabolism of protein, as neither subject had even an approximately adequate caloric intake during these periods. In both the latter instances potassium seems to have been excreted without its full complement of cell water since sodium and chloride losses were nearly sufficient to account for the decrease in weight of the body. As with other electrolytes, loss of potassium was made good promptly on the days subsequent to fever.

Alkalosis has been reported in artificial fever $(29,30)$. According to Danielson et al. (29), the $\mathrm{pH}$ of the serum was highest at the end of the period of induction and tended to fall somewhat as fever was prolonged. The alkalosis seemed to depend upon hyperventilation which brought about a primary carbon dioxide deficit. With hyperthermia lasting for 2 hours or more, there was a fall in the level of total base in serum and a decrease in $\mathrm{BHCO}_{3}$ and $\mathrm{BCl}$ which together exceeded the decrease in base.

In our patients the electrolyte pattern of the blood serum reflected the net losses during fever. The sodium concentration of the serum decreased more than the sum of the decreases in bicarbonate and chloride and suggested a primary base deficit. It is possible, however, that increases in other cations may have offset the losses of sodium.

Proper preparation of the patient directed toward insuring normal hydration and electrolyte content of the body, and replacement of water and salt during the exposure to high temperature should, in a great measure, prevent development of symptoms of dehydration and electrolyte loss. Storage of extra salt before fever in healthy individuals probably can not be accomplished in appreciable amounts unless very large quantities are given or there has been previous depletion. $\mathrm{Pa}$ tient W. D. was given 20 grams of additional sodium chloride for 2 days before fever and retained about 3.3 grams ( 56.8 m.eq. of $\mathrm{Na}$ and 57.8 m.eq. of $\mathrm{Cl}$ ); however, she had previously been on the relatively low salt intake of 2.5 grams per day. When Baird and Haldane (31) administered sodium chloride to healthy individuals in excess of their ability to excrete it (35 to 40 grams given during 2 hours) visible edema was produced and lasted for 8 to 24 hours. While no information is available concerning the extent to which the plasma volume is increased during such expansion of extracellular fluid, the findings of McQuarrie et al. (32) suggest that this may be quite large. These investigators found that when high salt feedings were continued several days marked elevations of blood pressure were produced. Such effects would be undesirable in patients with myocardial impairment.

The variations which characterize the individual patient's ability to excrete water and electrolytes make it difficult to state within fairly wide limits the individual's requirements during fever. Gibson and Kopp (8) have shown that the greatest shrinkage in the serum volume occurs during the rise and first hour of fever, and this is the period of most marked sweating. The magnitude of this deficit is probably influenced by the method of induction of fever, as well as the constitution of the patient (physical and mental status), previous food and water intake, individual differences in the activity of the sweat glands, and probably other factors. The losses through the skin are extensive enough in some cases to bring on a large deficit of salt and water. The kidneys then cease to produce urine. Other data (not included here) indicate that moderate sweating can continue during artificial fever only in the presence of adequate hydration of the body. Under such circumstances the kidneys continue to form urine. Cessation of sweating is a danger signal which should never be disregarded. Its significance as an indication of deficient fluid and sodium chloride is well illustrated in one of the reported cases (S. B.) who showed the greatest losses. His physical status appeared unsatisfactory during treatment. For this reason fever was stopped 12 hours sooner than had been the original intention. Patient W. D., on the other hand, who had a smaller net loss of salt withstood a longer period of treatment in comparative comfort. Continued moderate sweating and the output of small quantities of urine every few hours seem to be good clinical guides and indicate the presence of adequate fluid and electrolytes.

\section{SUMMARY}

Electrolyte balances were measured before, during, and after artificial fever maintained at comparatively low levels $\left(39.5^{\circ} \mathrm{C}\right.$. and $40.5^{\circ} \mathrm{C}$.). 
Skin losses were measured on a control day and during the fever.

The skin losses of sodium and chloride during fever represented from 7 to 19 per cent and the net losses from 7 to 22 per cent of the amount estimated to be in the extracellular water at the beginning of treatment.

Differences in the losses through the skin were dependent largely upon variations in ability of the individual to sweat.

At the end of fever there was evidence of slight anhydremia.

Three patients lost more sodium than chloride, one patient more chloride than sodium in the sweat.

In 3 of the patients the concentration of sodium, chloride, and carbon dioxide of the serum water were decreased; in one they were increased.

The 2 patients showing the greatest losses of water developed symptoms which resembled heat cramps.

Adequate storage beforehand, and replacement during treatment, particularly of sodium chloride and water, is necessary to prevent the development of symptoms of dehydration.

\section{BIBLIOGRAPHY}

1. Dill, D. B., Life, Heat, and Altitude. Harvard University Press, Cambridge, 1938.

2. Adolf, E. F., Heat exchanges of man in the desert. Am. J. Physiol., 1938, 123, 486.

3. Talbott, J. H., Heat cramps. Medicine, 1935, 14, 323.

4. Talbott, J. H., Dill, D. B., Edwards, H. T., Stumme, E. H., and Consolazio, W. V. The ill effects of heat upon workmen. J. Indust. Hyg. and Toxicol., 1937, 19, 258.

5. Moon, V. H., Shock, its mechanism and pathology. Arch. Path., 1937, 24, 642.

6. Loeb, R. F., Atchley, D. W., and Stahl, J., The rôle of sodium in adrenal insufficiency. J. A. M. A., 1935, 104, 2149.

7. Kopp, I., and Solomon, H. C., Shock syndrome in therapeutic hyperpyrexia. Arch. Int. Med., 1937, 60, 597.

8. Gibson, J. G., 2d, and Kopp, I., Studies in the physiology of artificial fever. I. Changes in the blood volume and water balance. J. Clin. Invest., 1938, $17,219$.

9. Stecher, R. M., and Solomon, W. M., The complications and hazards of fever therapy. Analysis of
1000 consecutive fever treatments in the Kettering hypertherm. Ann. Int. Med., 1937, 10, 1014.

10. Ebaugh, F. G., Barnacle, C. H., and Ewalt, J. R., Delirious episodes associated with artificial fever. Am. J. Psychiat., 1936, 93, 191.

11. Wilbur, E. L., and Stevens, J. B., Morbid anatomic changes following artificial fever, with reports of autopsies. South. M. J., 1937, 30, 286.

12. Hartman, F. W., and Major, R. C., Pathological changes resulting from accurately controlled artificial fever. Am. J. Clin. Path., 1935, 5, 392.

13. Bassett, S. H., Elden, C. A., and McCann, W. S., The mineral exchanges of man. I. Organization of metabolism ward and analytical methods. J. Nutrition, 1931, 4, 235.

14. Peters, J. P., and Van Slyke, D. D., Quantitative Clinical Chemistry. Vol. II. Methods. Williams and Wilkins Co., Baltimore, 1932.

15. Birner, M., Eine verbesserte Methode zur Chlorbestimmung in Organen und Nahrungsmitteln. Ztschr. f. d. ges. exper. Med., 1928, 61, 700.

16. McCance, R. A., Experimental sodium chloride deficiency in man. Proc. Roy. Soc., London, s.B., 1936, 119, 245.

17. Freyberg, R. H., and Grant, R. L., Loss of minerals through the skin of normal humans when sweating is avoided. J. Clin. Invest., 1937, 16, 729.

18. Dill, D. B., Jones, B. F., Edwards, H. T., and Oberg, S. A. Salt economy in extreme dry heat. J. Biol. Chem., 1933, 100, 755.

19. Gamble, J. L., Ross, G. S., and Tisdall, F. F., The metabolism of fixed base during fasting. J. Biol. Chem., 1923, 57, 633.

20. Bishop, F. W., Lehman, E., and Warren, S. L., A comparison of three electrical methods of producing artificial hyperthermia. J. A. M. A., 1935, 104, 910.

21. Eisenman, A. J., Mackenzie, L. B., and Peters, J. P., Protein and water of serum and cells of human blood, with a note on the measurement of red blood cell volume. J. Biol. Chem., 1936, 116, 33.

22. Peters, J. P., Body Water. Thomas, Springfield, 1935.

23. Manery, J. F., Danielson, I. S., and Hastings, A. B., Connective tissue electrolytes. J. Biol. Chem., 1938, 124, 359.

24. McSwiney, B. A., The composition of human perspiration. Proc. Roy. Soc. Med., 1934, 27, 839.

25. Fishberg, E. H., and Bierman, W., Acid-base balance in sweat. J. Biol. Chem., 1932, 97, 433.

26. Yannet, H., and Darrow, D. C., The effect of hyperthermia on the distribution of water and electrolytes in brain, muscle and liver. J. Clin. Invest., 1938, 17, 87.

27. Luciani, L. L. (transl. by Welby, F. A.), Human Physiology. Macmillan and Co., London, 1913, Vol. 2, p. 486 .

28. Warren, S. L., Chloride balance in artificial fever. Abstracts and discussions of papers presented at 
the first International Conference on Fever Therapy, Hoeber, New York, 1937, p. 34.

29. Danielson, W. H., Stecher, R. M., Muntwyler, E., and Myers, V. C., The acid-base balance of the blood serum in hyperthermia. Am. J. Physiol., 1938, 123, 550.

30. Gibson, J., Kopp, I., and Pijoan, M., Acid-base balance during therapeutic fever. Abstracts and Discussion of papers presented at First International
Conference on Fever Therapy. Hoeber, New York, 1937, p. 33.

31. Baird, M. M., and Haldane, J. B. S., Salt and water elimination in man. J. Physiol., 1922, 56, 259.

32. McQuarrie, I., Thompson, W. H., and Anderson, J. A., Effects of excessive ingestion of sodium and potassium salts on carbohydrate metabolism and blood pressure in diabetic children. J. Nutrition, 1936, 11, 77. 